\title{
Relationship Between Customer Perceived Value and Loyalty of Mobile Banking
}

\author{
Wei Xin ${ }^{1, a}$, He Changzheng ${ }^{1, b}$, Zhu bing ${ }^{1, c}$ \\ ${ }^{1}$ Management Science, School of business, Sichuan University, Chengdu, 401120, China \\ awei_xin111@sina.com, ${ }^{b} 15787040 @ q q . c o m,{ }^{c}$ satellite111@sina.com
}

\begin{abstract}
Mobile banking is regarded as main recommended business of all commercial banks at present. Its research in academia is very deficient. In the paper, influence relationship of perceived value on loyalty is discussed. The customer perceived value of mobile banking is subdivided into functional value, service value, emotional value, social value and perceived safety according to study of customer perceived value theory. Hypothetical model of perceived value influence on loyalty with customer satisfaction as mediating variable is proposed. Method of reliability and validity analysis, correlation analysis and regression analysis on sample with SPSS is utilized for verifying hypothesis test of the model through questionnaire. It is discovered that functional value, perceived safety and service value are affecting customer loyalty in turn according to degree. Emotional value and social value have no significant influence on loyalty.
\end{abstract}

Keywords-mobile banking; customer perceived value; loyalty; correlation analysis; regression analysis

\section{INTRODUCTION}

Mobile banking is mainly recommended by banks at present. However, academia research on mobile banking is fewer. At present, domestic and foreign academic research also focus on whether customers adopt influence factors of mobile banking or not. T.Laukkanen[1][2] study found that there are three barriers when mobile banking is accepted- use barrier, price barrier and risk barrier. There are some studies on mobile banking adoption influence factors in China and foreign countries; however study on loyalty after mobile banking opening is still blank. $60 \%$ of bank profit can be increased by reducing customer loss rate of $5 \%$. It is very critical for all commercial banks to improve own competitiveness by improving loyalty of existing customers. More satisfactory perceived value should be provided for customers firstly in order to improve customer loyalty.

Zeithaml firstly proposed e concept of customer perceived value from the perspective of customer in 1988. The value is defined as follows: After customer balance product profit and cost paid for obtaining product or services, product or service is evaluated as a whole. Customer perceived value has become a hot topic in the field of marketing in recent years, more and more scholars pay attention to it. Scholars basically believe that customer perceived value is mainly composed of perceived usefulness and perceived cost. However, different scholars believe that concrete dimensions for composting perceived usefulness and perceived cost are different. Namely, perceived value refers to comparison relation between payment and profit during service acquisition process. Wang Yonggui [3] recognizes four key dimensions with financial industry as background, namely functional value, emotional value, social value and perceived benefit loss. Meanwhile, many scholars [4] propose that service value is also one of important dimensions aiming at financial industry and online banking. Therefore, features of mobile banking are combined on the basis. Customer perceived value of mobile banking is divided several parts. Influence model of mobile banking customer perceived value on loyalty will be established in the subsequent study, thereby discussing their relationship.

\section{MODEL DESIGN}

Current academia generally recognizes Oliver[5] definition of customer loyalty: the customer highly promises that he can always purchase preferred product or services in the future, thereby producing repeated purchase behavior on series products or services in the same brand. No transfer behavior can be produced due to market trend change and competitive product marketing market attraction. Most scholars make related study on loyalty in recent years. Different scholars make related connotation and evaluation mode on loyalty from different perspectives. In the study, loyalty tests from two dimensions of attitudinal loyalty (customer attitude, intentions and repurchase probability) and behavioral loyalty (renewal will and possibility of recommending to others), proposed by Peltier and Westfall[6], are adopted. The relationship between customer value and customer loyalty is much studied. Most conclusions believe that customer value drives customer loyalty. For example, foreign scholars McDougall[7], etc. discovered in research of service industry that there is positive influence relationship between perceived value and customer loyalty. Therefore, since this study mainly emphasizes influence of perceived value on loyalty, model design is shown in Fig .1. Namely, customer perceived value has a direct impact on customer loyalty and satisfaction. Customer satisfaction has direct impact on customer loyalty. Meanwhile, customer satisfaction plays an intermediary role between customer perceived value and customer loyalty. 


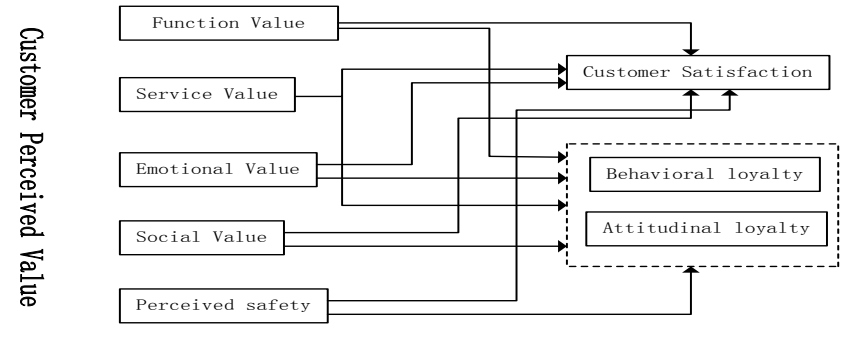

Figure 1. Relationship Model among Customer Perceived Value, Customer Satisfaction and Customer Loyalty

\section{SURVEY INDICATOR ANALYSIS AND DESIGN}

Survey method is adopted in the study for empirical research. Questionnaire consists of two parts: the first part is a sample statistic survey including gender, age, income, mobile bank and other basic information, and the information is used for descriptive statistics of samples. The second part is 7 Weilikete scale about study factor customer perceived value, customer satisfaction and loyalty. The author conducted a consultation from experts in academic team. Then, he discussed with employees in the bank, and implemented small-scale interview with some users of mobile banking, thereby collecting opinions from various aspects, and forming final test scale.

\section{DATA PROCESSING AND MODEL VALIDATION}

\section{A. Reliability Analysis}

Cronbach's $\alpha$ value is firstly utilized for testing internal consistency of questionnaire. In the study, SPSS17.0 statistical software is applied for reliability analysis on various variables of dependent variables and independent variables aiming at scale of customer loyalty influence factors of mobile banking. Cronbach's $\alpha$ value is obtained as shown in Table 1.Table 1 shows that questionnaire reliability Cronbach's $\alpha$ coefficient is above 0.8. The questionnaire in this study has a relatively good reliability. There is strong correlation among measurement indicators besides relatively excellent internal stability and consistency as well as higher reliability.

TABLE I. RELIABILITY AND VALIDITY CHECKING LIST

\begin{tabular}{|c|c|c|c|c|c|c|c|c|c|}
\hline $\begin{array}{l}\text { Research } \\
\text { Variable }\end{array}$ & Indicator & $\begin{array}{l}\text { Factor } \\
\text { Load }\end{array}$ & $\begin{array}{l}\text { Variable } \\
\text { Degree }\end{array}$ & $\begin{array}{l}\text { Cronbach } \\
\alpha \text { Value }\end{array}$ & $\begin{array}{l}\text { Research } \\
\text { Variable }\end{array}$ & Indicator & $\begin{array}{l}\text { Factor } \\
\text { Load }\end{array}$ & $\begin{array}{l}\text { Variable } \\
\text { Degree }\end{array}$ & $\begin{array}{l}\text { Cronbach } \\
\alpha \text { Value }\end{array}$ \\
\hline \multirow{3}{*}{$\begin{array}{c}\text { Behavioral } \\
\text { Loyalty }\end{array}$} & XW1 & 0.912 & \multirow[t]{3}{*}{0.741} & \multirow[t]{3}{*}{0.802} & \multirow{3}{*}{$\begin{array}{c}\text { Emotional } \\
\text { Value }\end{array}$} & QG1 & 0.735 & \multirow[t]{3}{*}{0.715} & \multirow[t]{3}{*}{0.901} \\
\hline & XW2 & 0.831 & & & & QG2 & 0.809 & & \\
\hline & XW3 & 0.812 & & & & QG3 & 0.743 & & \\
\hline \multirow{3}{*}{$\begin{array}{l}\text { Attitudinal } \\
\text { Loyalty }\end{array}$} & TD1 & 0.897 & \multirow[t]{3}{*}{0.746} & \multirow[t]{3}{*}{0.876} & \multirow{3}{*}{$\begin{array}{l}\text { Social } \\
\text { Value }\end{array}$} & SH1 & 0.787 & \multirow[t]{3}{*}{0.703} & \multirow[t]{3}{*}{0.813} \\
\hline & TD2 & 0.922 & & & & $\mathrm{SH} 2$ & 0.732 & & \\
\hline & TD3 & 0.788 & & & & $\mathrm{SH} 3$ & 0.780 & & \\
\hline \multirow{3}{*}{$\begin{array}{l}\text { Customer } \\
\text { Satisfaction }\end{array}$} & MY1 & 0.919 & \multirow[t]{3}{*}{0.812} & \multirow[t]{3}{*}{0.826} & \multirow{3}{*}{$\begin{array}{c}\text { Functional } \\
\text { Value }\end{array}$} & GN1 & 0.921 & \multirow[t]{3}{*}{0.728} & \multirow[t]{3}{*}{0.923} \\
\hline & MY2 & 0.841 & & & & GN2 & 0.913 & & \\
\hline & MY3 & 0.854 & & & & GN3 & 0.791 & & \\
\hline \multirow{3}{*}{$\begin{array}{l}\text { Service } \\
\text { Value }\end{array}$} & FY1 & 0.823 & \multirow[t]{3}{*}{0.739} & \multirow[t]{3}{*}{0.889} & \multirow{3}{*}{$\begin{array}{c}\text { Perceived } \\
\text { Safety }\end{array}$} & GZ1 & 0.866 & \multirow[t]{3}{*}{0.831} & \multirow[t]{3}{*}{0.876} \\
\hline & FY2 & 0.858 & & & & GZ2 & 0.921 & & \\
\hline & FY3 & 0.823 & & & & GZ3 & 0.835 & & \\
\hline
\end{tabular}

\section{B. Validity Analysis}

In the study, factor analysis method can be used for testing validity. KMO and Bartlett Spherical Test can be conducted firstly before factor analysis. Calculation results in table 2 show that KMO values of various variables are not lower than 0.60 . In addition, significant probability of Bartlett spherical test is $\mathrm{P}<0.01$, namely the result is significant. It is in line with research standard available for factor analysis. Then, factor analysis method in SPSS is used for respectively analyzing factors of all indicators. Factor load of each variable measurement indicator on the research scalar is calculated, and concrete results are shown in table 2 . Most factor loads of each measurement indicator are above 0.8, which is in line with validity test requirements. In addition, total explanation degree of all variable measurement indicators on research variable is also tested in the paper. Test result in table 2 shows that the designed research variable measurement indicator has higher explanation degree on research variable, which is higher than $70 \%$. It is visible that research scalar measurement indicator is set more rationally, which can be further researched and analyzed.

\section{Correlation Analysis}

In the paper, Pearson correlation coefficient in SPSS is utilized for analyzing two-variable correlation degree. Related coefficient and possibility between two variables are gradually calculated. The results are shown in table 2.In the study, SPSS is applied for respectively implementing correlation analysis Customer satisfaction, service value, emotional value, social value, functional value, perceived safety and three variables of attitudinal loyalty, behavioral loyalty and customer satisfaction. It is discovered that emotional value and social value have no relation with loyalty and customer satisfaction at 0.05 significance. Therefore, the study hypothesis that emotional and social values can positively affect loyalty and customer satisfaction is not established, and the hypothesis that function, service and security value 
TABLE II. CORRELATION COEFFICIENT TABLE

\begin{tabular}{llllllll}
\hline & & $\begin{array}{l}\text { Customer } \\
\text { satisfaction }\end{array}$ & $\begin{array}{l}\text { Service } \\
\text { value }\end{array}$ & $\begin{array}{l}\text { Emotional } \\
\text { value }\end{array}$ & $\begin{array}{l}\text { Social } \\
\text { value }\end{array}$ & $\begin{array}{l}\text { Functional } \\
\text { value }\end{array}$ & Perceived safety \\
\hline Behavioral & pearon & 0.632 & 0.372 & -0.182 & 0.154 & 0.175 & 0.421 \\
loyalty & Significance & $<0.001$ & $<0.001$ & 0.301 & 0.131 & $<0.001$ & $<0.001$ \\
Attitudinal & pearon & 0.571 & 0.545 & 0.329 & 0.246 & 0.227 & 0.412 \\
loyalty & Significance & $<0.001$ & $<0.001$ & 0.232 & 0.202 & $<0.001$ & $<0.001$ \\
Customer & pearon & & 0.473 & 0.175 & 0.329 & 0.233 & 0.375 \\
satisfaction & Significance & & $<0.001$ & 0.091 & 0.143 & $<0.001$ & $<0.001$
\end{tabular}

\section{Regression Analysis}

In the study, regression analysis is utilized for analyzing and discovering how respective variables act on dependent variables, and influence on dependent variables. In the study, SPSS is applied for adopting multivariate forced regression analysis method, and behavioral loyalty, attitudinal loyalty and satisfaction are regarded as regression model of dependent variables in order to further research relation between customer loyalty influence factor and customer loyalty as well as function mechanism among customer loyalty influence factors. It is proved previously that emotional value and social value have significant correlation with loyalty and customer satisfaction; therefore the two variables cannot enter the subsequent regression analysis model.Now this is the regression Analysis of Behavioral Loyalty and Influence Factors Thereof. Behavioral loyalty, attitudinal loyalty and customer satisfaction are regarded as the dependent variables respectively. Customer satisfaction, service value, functional value and perceived safety are regarded as independent variables for regression analysis. The results are shown in Table 3 .

TABLE III. REGRESSION TABLE OF BEHAVIORAL LOYALTY

\begin{tabular}{|c|c|c|c|c|c|c|c|}
\hline Dependent Variable & Model & Beta & Standard Beta & $\mathrm{t}$ & sig & $\mathrm{R}^{2}$ & $\mathrm{~F}$ \\
\hline \multirow[t]{4}{*}{ Behavioral loyalty } & $\begin{array}{l}\text { Customer } \\
\text { satisfaction }\end{array}$ & 0.291 & 0.265 & 1.824 & 0.002 & \multirow[t]{4}{*}{0.646} & \multirow[t]{4}{*}{$\begin{array}{l}61.774 \\
1<0.001\end{array}$} \\
\hline & Service value & 0.288 & 0.225 & 2.629 & $<0.001$ & & \\
\hline & $\begin{array}{l}\text { Functional } \\
\text { value }\end{array}$ & 0.357 & 0.326 & 2.717 & $<0.001$ & & \\
\hline & $\begin{array}{l}\text { Perceived } \\
\text { safety }\end{array}$ & 0.332 & 0.302 & 3.418 & $<0.001$ & & \\
\hline \multirow[t]{4}{*}{ Attitudinal loyalty } & $\begin{array}{l}\text { Customer } \\
\text { satisfaction }\end{array}$ & 0.266 & 0.237 & 2.561 & $<0.001$ & \multirow[t]{4}{*}{0.587} & \multirow[t]{4}{*}{$\begin{array}{l}56.783 \\
K<0.001\end{array}$} \\
\hline & Service value & 0.239 & 0.218 & 2.526 & $<0.001$ & & \\
\hline & $\begin{array}{l}\text { Functional } \\
\text { value }\end{array}$ & 0.368 & 0.351 & 2.965 & $<0.001$ & & \\
\hline & $\begin{array}{l}\text { Perceived } \\
\text { safety }\end{array}$ & 0.343 & 0.328 & 2.475 & $<0.001$ & & \\
\hline \multirow{3}{*}{$\begin{array}{l}\text { Customer } \\
\text { Satisfaction }\end{array}$} & Service value & 0.284 & 0.265 & 1.856 & $<0.001$ & \multirow[t]{3}{*}{0.531} & \multirow{3}{*}{$\begin{array}{l}46.481 \\
K<0.001\end{array}$} \\
\hline & $\begin{array}{l}\text { Functional } \\
\text { value }\end{array}$ & 0.409 & 0.373 & 2.743 & $<0.001$ & & \\
\hline & $\begin{array}{l}\text { Perceived } \\
\text { safety }\end{array}$ & 0.354 & 0.331 & 2.879 & $<0.001$ & & \\
\hline
\end{tabular}

$\mathrm{R} 2$ and $\mathrm{F}$ values of three regression results are observed. It is indicated that regression equations are valid. Wherein, regression coefficients of respective variables in behavioral loyalty are $0.265,0.225,0.326$ and 0.302. In is indicated that functional value, perceived safety and service value affect behavioral loyalty in turn according to degree. Similarly, the order also positively and significantly affects attitudinal loyalty and customer satisfaction according to the same order.

\section{CONCLUSIONS}

In the paper, status of personal mobile banking industry in China is combined after literature research and theory review. Customer perceived values are divided into functional value, service value, emotional value, social value and perceived safety; influence model of loyalty is constructed (including behavioral loyalty and attitudinal loyalty). The following innovations are achieved: 1. mobile banking customer perceived value segmentation dimensions are accurately defined firstly, and 'perceived security', the dimension different from other industries is proposed. 2 . It is found in mobile banking is different from other industries in that emotion and social value have no significant impact on loyalty. Functional value, perceived safety and service value can affect loyalty and customer satisfaction in turn according to degree. In the paper, the reason why emotion and social value have no significant influence on loyalty is not discussed in the paper due to limitation 
in data and article size. It will be a key direction of further study in the future.

\section{REFERENCES}

[1] Nicole Koenig-Lewis. Predicting young consumers' take up of mobile banking services[J].International JournalofBankMarketing, 201028(5) 410-432.

[2] TLaukkanen. Customer preferred channel attributes in multi-channel electronic banking[J]. International Journal of Retail \& Distribution Management, 20077 (3) 393-412.

[3] Wang Yonggui, Customer Resource Management: Assets, Relation, Value and Knowledge [M]. Beijing: Beijing University Publishing House, 2005.

[4] Cheng Haiqing.Client Value Driving Factors [J]. Soft Science, 200721(2)48-59.
[5] R. L. Oliver. Whence consumer loyalty[J]. Journal of Marketing 2009 63(5)33 44.

[6] PeltierJ, WDissecting. Benefits Managers Relationship : What to Measure and Why[J].Marketing Health Services , 200020(2)4-13.

[7] McDougall. International Entrepreneurship: the Intersection of Two Research Paths[J]. Academy of Management Journal, 200043(5) 902-908.

[8] Xie Y, Li X, Ngai E, Ying W. Customer churn prediction using improved balanced random forests[J]. Expert Systems with Applications, 200936 (3): 5445-5449.

[9] Wiginton J.C. A note on the comparison of logit and discriminant models ofconsumer credit behavior [J]. Journal of Financial and Quantitative Analysis,198015: 757-770.

[10] EM Agwu, AL Carter. Mobile phone banking in Nigeria: benefits, problems and prospects[J]. International Journal of Business and Commerce,2014(3):43-55. 